\title{
Clinical-anamnestic characteristic of first-year children with CNS hipoxyc-ischemic injury
}

\author{
L. 0. Volotko(i)* \\ Zaporizhzhia Regional Clinical Children’s Hospital, Ukraine
}

Diseases of the nervous system occupy the second place among the causes of childhood disability. Perinatal injuries of the nervous system constitute up to $65-75 \%$ of all diseases of the nervous system in childhood and lead to disability in 15-30\% of full-term newborns, $40-60 \%$ of born prematurely.

Aim: to provide the clinical-anamnestic characteristics of newborns with hypoxic-ischemic CNS injury.

Materials and methods. The study included 100 newborns. The main group - 31 patients with CNS hypoxic-ischemic injury complicated by an infectious process, the comparison group - 35 patients with CNS hypoxic-ischemic injury without the infectious process, the control group - 34 conditionally healthy children born without signs of CNS hypoxic-ischemic injury and inflammatory diseases. In the course of the work, the clinical-anamnestic method and the methods of mathematical statistics were used. Statistical processing of results was performed using license program package Statistica 13.0 (StatSoft Inc., serial number JPZ8041382130ARCN10-J).

Results. It was found that it is impossible to assess the condition of newborns without taking into account an obstetric history due to the fact that complications of the prenatal period lead to the action of harmful factors of different nature on an immature fetus and can cause severe damage including the development of hypoxic-ischemic brain injury.

Conclusions. Prematurely born children with hypoxic-ischemic CNS injury complicated by the infectious process, unlike conditionally healthy prematurely born children, are characterized by low gestational age $(29.55 \pm 4.20$ weeks and $36.0 \pm 0.0$ weeks, respectively), the prevalence of pathology in the second half of pregnancy and threatened miscarriage. The presence of a complicated obstetric history greatly increases the possibility of hypoxic-ischemic brain injury in newborns, and its infectious-inflammatory complication is more likely to develop in children with low body weight and low Apgar scores. The phenomena of hypoxia, both hypoxic and circulatory, are more common for patients who were born prematurely.

\section{Кмініко-анамнестична характеристика дітей першого року життя 3 гіпоксично-ішемічним ураженням ЦНС}

\section{А. О. Волотко}

Хворобам нервової системи належить друге місце серед причин дитячої інвалідності. Перинатальні ураження нервової системи становлять до 65-75 \% усіх захворювань нервової системи в дитячому віці та призводять до інвалідизації 15-30 \% доношених новонароджених, 40-60 \% передчасно народжених, зокрема чималої кількості дітей, які народжені з екстремально низькою масою тіла.

Мета роботи - надати клініко-анамнестичну характеристику новонароджених із гіпоксично-ішемічним ураженням ЦНС.

Матеріали та методи. Обстежили 100 новонароджених дітей: основна група - 31 пацієнт із гіпоксично-ішемічним ушкодженням ЦНС, що ускладнилось інфеекційним процесом; група порівняння - 35 пацієнтів із гіпоксично-ішемічним ураженням ЦНС без інфекційного процесу; контрольна група - 34 умовно здорових дітей, які народилися без ознак гіпоксично-ішемічного ушкодження нервової системи та запальних захворювань. Протягом роботи використали клініко-анамнестичний метод, методи математичної статистики. Статистичне опрацювання результатів виконали, використовуючи ліцензійний пакет програм Statistica 13.0 (StatSoft Inc., серійний номер JPZ8041382130ARCN10-J).

Результати. Встановили, що неможливо оцінювати стан новонародженої дитини, не враховуючи акушерський анамнез перебігу вагітності, оскільки ускладнення пренатального періоду призводять до дії різноманітних шкідливих фракторів на незрілий організм плода та можуть спричиняти тяжкі ушкодження, як-от розвиток гіпоксично-ішемічного ураження головного мозку.

Висновки. Передчасно народжені діти з гіпоксично-ішемічним ушкодженням ЦНС, що ускладнене інфекційним процесом, на відміну від умовно здорових передчасно народжених дітей, характеризуються низьким гестаційним віком (29,55 \pm 4,20 тижня та 36,0 \pm 0,0 тижня відповідно), поширеністю патології другої половини вагітності та загрози переривання вагітності. Наявність ускладненого акушерського анамнезу суттєво збільшує можливість виникнення гіпоксично-ішемічного ураження головного мозку в новонароджених, а його інфекційно-запальне ускладнення, найімовірніше, виникне в дітей із низькою масою тіла та низькими показниками за шкалою Апгар. Явища і гіпоксичної, і циркуляторної гіпоксії характерніші для хворих із гіпоксично-ішемічним ушкодженням ЦНС, які народжені достроково.
Key words: brain hypoxia, prenatal injures, premature birth.

\section{Zaporozhye} medical journa 2020; $22(5), 617-621$

*E-mail: volotkoludmila@ gmail.com
Киючові слова: гіпоксія мозку, пренатальні травми, передчасні пологи.

Запорізький медичний журнал 2020. T. 22, № 5(122). C. $617-621$

\section{Киинико-анамнестическая характеристика детей первого года жизни с гипоксически-ишемическим поражением ЦНС}

\section{А. А. Волотко}

Болезни нервной системы занимают второе место среди причин детской инвалидности. Перинатальные поражения нервной системы составляют до 65-75 \% всех заболеваний нервной системы в детском возрасте и ведут к инвалидизации 
Ключевые слова: гипоксия мозга, пренатальные травмы, преждевременные роды.

Запорожский медицинский журнал. 2020. T. 22, № 5(122) C. $617-621$

15-30 \% доношенных новорожденных, 40-60 \% преждевременно рожденных, в том числе значительного количества детей, рожденных с экстремально низкой массой тела.

Цель работы - дать клинико-анамнестическую характеристику детей первого года жизни с гипоксически-ишемическим поражением ЦНС.

Материалы и методы. Обследовали 100 новорожденных детей: основная группа - 31 пациент с гипоксически-ишемическим поражением ЦНС, которое осложнено инфекционным процессом; группа сравнения - 35 пациентов с гипоксически-ишемическим поражением ЦНС без наличия инфекционного процесса; контрольная группа - 34 условно здоровых детей, родившихся без признаков гипоксически-ишемического поражения нервной системы и воспалительных заболеваний. В ходе работы использованы клинико-анамнестический метод, методы математической статистики. Статистическую обработку результатов выполнили с использованием лицензионного пакета программы Statistica 13.0 (StatSoft Inc., серийный номер JPZ8041382130ARCN10-J).

Результаты. Установлено, что невозможно оценивать состояние новорожденного ребенка без учета акушерского анамнеза течения беременности, т. к. осложнения пренатального периода приводят к действию вредных фракторов различной природы на незрелый организм плода и могут обусловливать тяжелые повреждения, включая развитие гипоксическиишемического поражения головного мозга.

Выводы. Недоношенные дети с гипоксически-ишемическим поражением ЦНС, осложненным инфекционным процессом, в отличие от условно здоровых недоношенных детей, характеризуются низким гестационным возрастом (29,55 \pm 4,20 недели и 36,0 \pm 0,0 недели соответственно), преобладанием патологии второй половины беременности и угрозой прерывания беременности. Наличие осложненного акушерского анамнеза значительно увеличивает возможность возникновения гипоксически-ишемического поражения головного мозга у новорожденных, а его инфекционно-воспалительное осложнение, вероятнее всего, разовьется у детей с низкой массой тела и низкими показателями по шкале Апгар. Явления и гипоксической, и циркуляторной гипоксии более характерны для больных с гипоксически-ишемическим поражением ЦНС, которые рождены досрочно.

Currently, according to the Ministry of health statistic, the rise in infant disability takes place. So, for the last 3 years, the total disability in children as a whole was increased by $3.5 \%$ [5], including those due to diseases of the nervous system $9 \%$ [4]. According to 01.01 .2018 in Ukraine, there were 161.594 children with a disability, and that was $2 \%$ of all children. Diseases of the nervous system occupy the second place among the causes of childhood disability [4]. Prematurity plays a leading role in shaping the infant mortality rate [8]. According to the $\mathrm{WHO}$, mortality among children weighing less than $2500 \mathrm{~g}$ born alive is 14 per 1000. Of these, about $2 / 3$ of the deaths occur in children weighing less than $1500 \mathrm{~g}$ [8]. Moreover, although premature infants make up a relatively small proportion of all neonates, approximately $50 \%$ of cerebral palsy cases are diagnosed among these children [13,14]; severe neurological disabilities are also typical both for premature infants and in long term consequence [10,11] as well as intraventricular hemorrhages [15]. Most diseases of the nervous system, leading to disability and maladjustment among children, develop due to the perinatal factors influence in 70-80\% of cases [6,7]. Perinatal injuries of the nervous system constitute up to $65-75 \%$ of all diseases of the nervous system in children and lead to disability in $15-30 \%$ of fullterm newborns, 40-60\% in prematurely born, including a significant number of children born with extremely low body weight [9]. Among the most common factors that cause injury of the nervous system in the perinatal period is hypoxia [1,3], the development of which is resulted from the most adverse factors influence during pregnancy and delivery [2]. Perinatal hypoxia remains one of the leading causes of child mortality and disability, mostly due to an injury of the central nervous system (CNS), respiratory system, organs of sight and hearing, with the possible formation of later cerebral palsy (CP), structural epilepsy, blindness, deafness, hydrocephalus, etc. [5-7]. Analysis of anamnesis data, clinical examination, comparison of the pregnancy peculiarities, the results of genetic tests is a key confirmation of a correct clinical diagnosis [12] and the prediction of the disease development, its severity and long-term effects.

\section{Aim}

To provide the clinical-anamnestic characteristics of newborns with hypoxic-ischemic CNS injury.

\section{Materials and methods}

On the base of the Neonatal Intensive Care Unit and Neonatal Pathology Department of the Regional Clinical Children's Hospital (Zaporizhzhia), a comprehensive clinical examination of newborn children was conducted between 2017 and 2019.

A total of 100 newborn children were examined. All the children were divided into 3 groups. The first (main) group included 31 patients with hypoxic-ischemic CNS injuries complicated by an infectious process (meningitis, ventriculitis), the second group (comparison) - 35 patients with hypoxic-ischemic injuries of the CNS without the presence of the infectious process, the third (control) group - 34 conditionally healthy children born without signs of hypoxic-ischemic injuries of the nervous system and inflammatory diseases (Table 1). 5 prematurely born children were included in this group; all these patients were characterized by the absence of neurological pathology and infectious processes. The condition of the child was evaluated on admission at the Intensive Care Unit.

Criteria for inclusion in the study groups:

- children aged from the time of birth to 11 months 29 days;

- diagnosis of "hypoxic-ischemic injury of CNS", "intraventricular hemorrhage", "purulent meningitis, ventriculitis";

- parental consent for the study.

Exclusion criteria from the study:

- children older than 1 year; 
- the presence of organic pathology of the cardiovascular and respiratory systems;

- anomalies of the CNS development;

- the presence of other malformations in the stage of compensation;

- not obtained parental consent for the study.

In the course of the work, the clinical-anamnestic (physical examination data) method and the methods of mathematical statistics were used.

In accordance with the study objectives, the documentation was prepared and used in collecting and recording data concerning the health status of a mother: obstetric history (pregnancy, childbirth and the postpartum period) and physical status as well as a child's health status: clinical status (assessment of gestational and physical development of a child according to gestational age).

In the work, we respected the principles of bioethics: key provisions of the Convention of the Council of Europe on human rights and Biomedicine (04.04.1997), GCP (1996), World Medical Association Declaration of Helsinki (ethical principles for medical research involving human subjects (1964-2000)) and the order of the MOH of Ukraine No. 281 (01.11.2000).

Statistical processing of the obtained results was performed on a personal computer using the licensed software package Statistica 13.0 (StatSoft Inc, serial number JPZ8041382130ARCN10-J) by calculating the arithmetic mean (M), standard deviations $(\sigma)$ and mean errors $(m)$. The relationship between individual parameters was evaluated using the methods of Pearson's correlation. To assess differences in the indices between the groups compared, we used Student's t-criterion and $P$ values $<0.05$ were considered to indicate statistically significant differences.

\section{Results}

Among healthy newborns (34), full-term infants amounted to $82.3 \%$ (29 patients), gestational age was about $38.80 \pm 0.99$ weeks. The children were mainly from the first pregnancy $(48.4 \%)$, the first delivery $(58.1 \%)$. Clinical features of pregnancy, a somatic status of a pregnant woman play an important role in the development of various conditions which may be hazardous to a fetus and newborn child. Effects of some exogenous and endogenous factors in the antenatal period, negatively influencing the immature fetus, should be taken into account in predicting the course of labor and the condition of the infant in the early postnatal period. It was established that even among relatively healthy newborns, in some cases, burdened obstetric history in the mother was revealed: a pathology of the first half of pregnancy was detected in $32.3 \%$ (10 cases), pathology of the second half of pregnancy - in $45.2 \%$ (14 cases), there was a threat of miscarriage in $41.9 \%$ (13 cases). The obstetric history of prematurely born children revealed a pathology of the first half of pregnancy in $20 \%$ (1 case), a pathology of the second half of pregnancy in $60 \%$ (3 cases), and the same level (60\%) of threatened abortion (3 cases). Meanwhile, in the anamnesis of term-born children, these figures were much smaller: the pathology of the first half of pregnancy was detected in $31.03 \%$ (9 cases), the pathology of the second half - in $39.29 \%$ (11 cases), and threatened miscarriage - in $34.48 \%$ (10
Table 1. Distribution of patients according to gestational age and group of examination

\begin{tabular}{l|l|l|l} 
& Control group & Comparison group & Main group \\
\hline Prematurely born & 5 & 16 & 24 \\
Full-term newborns & 29 & 19 & 7 \\
\hline Total & 34 & 35 & 31 \\
\hline
\end{tabular}

cases). The Apgar score from 7 to 9 points was assigned to the majority of newborns in the group of conditionally healthy infants: infants born prematurely $-7.20 \pm 0.83$ points and full-term infants $-7.90 \pm 0.93$ points. The average birth weight was $3217.6 \pm 463.8 \mathrm{~g}$ (in the group of prematurely born $-2597.5 \pm 3135.0 \mathrm{~g}$, and in full-term infants $-3195.9 \pm 465.9 \mathrm{~g}$ ).

All preterm babies of the control group were male, and there were 19 boys (65.52\%) and 10 girls (34.48\%) among term-born children.

Among the comparison group children ( 35 babies) diagnosed with a hypoxic-ischemic brain injury within the first hours after birth, full-term newborns amounted to $54.3 \%$ (19 children), their gestational age ranged from 34 to 37 weeks, averaging about $35.9 \pm 4.2$ weeks. The children, as in the control group, were predominantly from the first pregnancy $(41.2 \%)$, the first birth $(44.1 \%)$. In general, compared to the control group, the pathology of the first $(55.9 \%)$ and second $(79.4 \%)$ halves of pregnancy was more frequently found, the threatened miscarriage was in 25 cases $(73.5 \%)$

The above data characterized predominantly preterm babies born to women with the pathology of the first half of pregnancy in $56.25 \%$ (9 cases), the pathology of the second half of pregnancy was revealed in $87.5 \%$ (14 cases) in the history of this group newborns, and the threatened miscarriage was almost absolute $(93.75 \%, 15$ cases out of 16 newborns). For infants who were born at term but diagnosed with hypoxic-ischemic brain injury within the first hours after birth, a gestational history was less burdened than that in preterm infants, but it was significantly worse than among conditionally healthy infants (Table 2). The average Apgar score was 6 in this group, but there were 6 preterm babies (40\%) born with asphyxia and an Apgar score of 2 to 5 . The average birth weight of newborns in this group was $2701.9 \pm 896.0 \mathrm{~g}, 3335.8 \pm 460.4 \mathrm{~g}$ among those born at term and $1899.0 \pm 621.1 \mathrm{~g}-$ among babies born preterm. There were 6 boys (37.5\%) and 10 girls $(62.5 \%)$ among prematurely born children, and boys were predominant among full-term babies (13 babies (68.42 \%)) compared to girls ( 6 babies (31.58\%)).

Among the main group (31 children) with hypoxicischemic injury of the CNS complicated by the infectious process (meningitis, ventriculitis), full-term infants amounted only to $22.6 \%$ (7 patients). Gestational age ranged between 27 and 37 weeks (average of $31.5 \pm 1.3$ weeks). The children were mainly from the second $(63.2 \%)$ and the third $(36 \%)$ pregnancy $(P<0.05)$, mostly the second delivery $(63.2 \%)$. The pathology of the first half of pregnancy was observed in 9 cases $(29.03 \%)$, the pathology of the second half $(54.84 \%, 17$ cases $)$ dominated, the threatened miscarriage was revealed in $58.06 \%$ of the cases (18 patients). These data were especially so for prematurely born children, in whom the pathology of the second half of pregnancy was identified in $62.5 \%$, 
Table 2. Clinical characteristic of patients

\begin{tabular}{|c|c|c|c|c|c|c|}
\hline \multirow[t]{2}{*}{ Indexes, units } & \multicolumn{2}{|c|}{ Control group, $n=34$} & \multicolumn{2}{|c|}{ Comparison group, $n=35$} & \multicolumn{2}{|l|}{ Main group, $n=31$} \\
\hline & $\begin{array}{l}\text { Full-term babies, } \\
n=29\end{array}$ & $\begin{array}{l}\text { Prematurely born, } \\
n=5\end{array}$ & $\begin{array}{l}\text { Full-term babies, } \\
n=19\end{array}$ & $\begin{array}{l}\text { Prematurely born, } \\
n=16\end{array}$ & $\begin{array}{l}\text { Full-term babies, } \\
\mathrm{n}=7\end{array}$ & $\begin{array}{l}\text { Prematurely born, } \\
n=24\end{array}$ \\
\hline Gestational age, weeks & $38.74 \pm 1.02$ & $36.0 \pm 0.0^{* *}$ & $39.2 \pm 1.1$ & $32.20 \pm 0.45^{*, \star \star}$ & $38.80 \pm 0.45$ & $29.55 \pm 4.20^{*}$ \\
\hline Pathology of the first half of pregnancy, $n$ & 9 & 1 & $10^{* *}$ & 9 & $1^{* *}$ & 8 \\
\hline Pathology of the second half of pregnancy, $n$ & 11 & 3 & 13 & 14 & 2 & 15 \\
\hline Threatened miscarriage, $\mathrm{n}$ & 10 & 3 & 10 & 15 & 1 & 17 \\
\hline Apgar score & $7.90 \pm 0.93^{*}$ & $7.20 \pm 0.83^{\star *}$ & $6.3 \pm 1.7^{*}$ & $5.6 \pm 1.7$ & $4.4 \pm 1.9^{*}$ & $5.1 \pm 1.4^{* *}$ \\
\hline Average birth weight, $\mathrm{g}$ & $3195.9 \pm 465.9$ & $2597.5 \pm 313.5^{* \star}$ & $3335.8 \pm 460.4$ & $1899.0 \pm 621.1^{*, * *}$ & $3156.0 \pm 521.7$ & $1407.0 \pm 570.1^{*}$ \\
\hline
\end{tabular}

*: statistically significant differences in the indices among full-term children of the comparison and main groups, the comparison and control groups $(\mathrm{P}<0.05)$; **: statistically significant differences in the indices among children born prematurely of the comparison and main groups, the comparison and control groups $(P<0.05)$.

and the threatened miscarriage - in $70.83 \%$ of the cases. In general, the average Apgar score was $5.00 \pm 1.68$ points in this group. The average birth weight was about $1756.8 \pm 901.4 \mathrm{~g}$, but it ranged from $960 \mathrm{~g}$ to 1690 and averaged $1407.0 \pm 570.1 \mathrm{~g}$ in preterm babies. Among fullterm newborns in this group, there were 5 boys $(71.43 \%)$ and 2 girls (28.57\%), and among prematurely born - 11 boys ( $45.83 \%$ ) and 13 girls (of $54.17 \%$ ).

Among the control group children, 5 patients (14.71\%) born at term had some violations of the cardiovascular system in the form of arrhythmia and ECG changes. In the comparison group of children with hypoxic-ischemic injury of the CNS with intraventricular hemorrhage, the signs of circulatory hypoxia were revealed in eight cases (22.86\%). Among these children, 5 were born at term, and three prematurely. But 17 patients (48.57\%) with symptoms of hypoxic hypoxia and apnea or pneumonia were identified among the comparison group patients as compared to the group of healthy children. Among these children, babies born prematurely predominated (10 patients).

Signs of circulatory and hypoxic hypoxia were detected in 3 infants of the comparison group (8.57\%). Among these children, 2 were born prematurely. Apnea and pneumonia which resulted in the development of hypoxic hypoxia were diagnosed in 12 patients of the main group with hypoxic-ischemic injury of the CNS and intraventricular hemorrhage (48\%), complicated by meningitis or ventriculitis. Among them, 9 patients were born prematurely. The signs of circulatory hypoxia were diagnosed in 9 patients (36\%), 7 of them were born prematurely. The symptoms of hypoxic and circulatory hypoxia were also revealed among the main group patients in 7 cases (28\%), 4 of these infants were born prematurely.

\section{Discussion}

Thus, it is impossible to assess the condition of newborns without taking into account an obstetric history due to the fact that complications of the prenatal period lead to the action of harmful factors of different nature on an immature fetus and can cause severe damage including the development of hypoxic-ischemic brain injury. Analyzing the data on the gestation course in all groups of children, it may be noted that the most significant difference in the data characterizing the pregnancy was revealed between the comparison and control groups. Namely, it was established that, in general, in the comparison group, the pathology of the first half of pregnancy was found 1.73 times (or $23.6 \%$ ) more frequently than in the control one.
Thus, this indicator was 1.7 times higher among the term babies than in the controls, and 2.81 times more among the preterm babies. In the comparison group children, diagnosed with hypoxic-ischemic brain injury within the first hours after birth, the pathology of the second half of pregnancy was also revealed 1.76 times more often than in the controls, 1.74 times more often in full-term newborns, 1.46 times - in prematurely born. The threatened miscarriage was also 1.75 times higher in the comparison group than in the control (1.53 times among term-born infants, and 1.75 times - among prematurely born).

When comparing data on the obstetric history between the main and control groups, more cases of pathology of the second half of pregnancy (1.21 times) and threatened abortion (1.38 times) were detected. The data obtained were more typical for prematurely born children. The main group children with hypoxic-ischemic brain injury, complicated by the infectious process, demonstrated significantly lower Apgar scores as compared to the control as well to the comparison group. Namely, among children born at term -1.8 times lower compared to the control group and 1.43 times lower than in the comparison group; among prematurely born children - 2.1 times lower compared to the controls and 1.1 times lower than in children with hypoxic-ischemic brain injury, not complicated by the infectious process. This index in the comparison group children was also lower than in the control one: in term born babies - 1.25 times, prematurely born -1.29 times.

The body weight of babies with hypoxic-ischemic brain injury, with or without infectious process, was significantly lower than in the controls. In particular, 1.37 times - in the comparison group, 1.85 times - in the main group. The body weight of prematurely born children with hypoxic-ischemic brain injury, complicated by inflammatory process was 1.34 times lower than in the comparison group. Patients with hypoxic-ischemic CNS injury demonstrated the symptoms of circulatory hypoxia 1.55 times more frequently compared to the controls and had disorders of the respiratory system (respiratory failure and pneumonia), and it was also more common for prematurely born children. The occurrence of circulatory hypoxia was 2.45 times higher in the main group of patients than in the control, and it was 1.57 times higher than in the comparison group.

The rate of hypoxic hypoxia coincided with the data of the comparison group, but the proportion of children with impaired function of respiratory and cardiovascular systems was 3.27 times higher than in the comparison group. Among these patients, prematurely born children with low Apgar scores and pathology of the second half of pregnancy and threatened miscarriage prevailed. 


\section{Conclusions}

1. Prematurely born children with hypoxic-ischemic CNS injury complicated by the infectious process, unlike conditionally healthy prematurely born children, are characterized by low gestational age $(29.55 \pm 4.20$ weeks and $36.0 \pm 0.0$ weeks, respectively), the prevalence of pathology in the second half of pregnancy and threatened miscarriage.

2. The presence of a complicated obstetric history greatly increases the possibility of hypoxic-ischemic brain injury in newborns, and its infectious-inflammatory complication is more likely to develop in children with low body weight and low Apgar scores.

3. The phenomena of hypoxia, both hypoxic and circulatory, are more common for patients with hypoxic-ischemic CNS injury who were born prematurely.

Prospects for the further research. The next step will focus on laboratory and instrumental examination of first year of life children with hypoxic-ischemic CNS injury, determination of the optimal tactics of treatment and rehabilitation measures.

\section{Funding}

The work was conducted as a part of scientific work of Shupyk National Medical Academy of Postgraduate Education (Kyiv) "The clinical-catamnestic studies of development in children with perinatal hypoxic-ischemic encephalopathy which were complicated by the infectious process" (2017-2021, state registration number 0118U001019).

Conflicts of interest: author has no conflict of interest to declare. Конфлікт інтересів: віАсутній.

Надійшла Ао реАакції / Received: 24.04.2020

Після Аоопрацювання / Revised: 11.05.2020

Прийнято Ао Аруку / Accepted: 21.05.2020

Information about authors:

Volotko L. O., MD, Head of Medical-Social Rehabilitation Center, Zaporizhzhia Regional Clinical Children's Hospital, Ukraine. ORCID ID: 0000-0003-1205-4973

\section{Відомості про автора:}

Волотко ^. О., зав. центру медико-соціальної реабілітації, КНП «Запорізька обласна кмінічна Аитяча лікарня» 3ОР, Україна.

\section{Сведения об авторе}

Волотко ^. А., зав. центром меАико-социальной реабилитации, КНП «Запорожская областная клиническая Аетская больница” 30С, Украина.

\section{References}

[1] Batysheva, T. T., Krapivkin, A. I., Tsaregorodtsev, A. D., Sukhorukov, V. S., \& Tikhonov, S. V. (2017). Reabilitatsiya detei s porazheniem tsentral'noi nervnoi sistemy [Rehabilitation of children with the pathology of central nervous system]. Rossiyskiy Vestnik Perinatologii i Pediatrii, 62(6), 7-15. https://doi.org/10.21508/1027-4065-2017-62-6-7-15 [in Russian].

[2] Bryksina, E. Yu., Bryksin, V. S., Bushtyreva, I. O., Bushtyrev, V. A., \& Onianget, E. P. (2015). Patogeneticheskie aspekty perinatal'nogo porazheniya tsentral'noi nervnoi sistemy i osobennosti nevrologicheskogo statusa nedonoshennykh detei [Pathogenetic aspects of perinatal defeat of the central nervous system and feature of the neurologic status of prematurely born children]. Sovremennye problemy nauki i obrazovaniya, (4). http://www.science-education.ru/ru/article/ view?id=21319 [in Russian].
[3] Vasil'eva, M. A., \& Potapova, V. E. (2017). Differentsial'naya diagnostika porazhenii TsNS u novorozhdennykh: znachenie likvorologicheskogo issledovaniya [Differential diagnosis of CNS lesions in newborns: the value of liquorological research]. Achievements of fundamental, clinical medicine and pharmacy: proceedings of the 72nd scientific. sess. of univ. staff, 25-26 Jan. 2017. (pp. 246-248). VGMU. [in Russian].

[4] Znamenska, T. K., Vorobiova, O. V., \& Dubinina, T. Yu. (2017) Stratehichni napriamky rekonstruktsii systemy okhorony zdorovia novonarodzhenykh ta ditei Ukrainy [Strategic directions for reconstruction of the health system newborns and children of Ukraine]. Neonatolohiia, khirurhiia ta perynatalna medytsyna, 7(4), 5-12. https:/l doi.org/10.24061/2413-4260.VII.4.26.2017.1 [in Ukrainian].

[5] Namasov-Baranova, L. S., Deev, I. A., Kobyakova, O. S., Kulikova, K. V., Kulikov, E. S., Zhelev, V. A., Deeva, E. V., Kolomeec, I. L., Belyaeva, I. A., Davydova, I. V., \& Mammadyarov, A. M. (2016). Osobennosti somaticheskoi patologii u detei s nizkoi, ochen' nizkoi i ekstremal'no nizkoi massoi tela pri rozhdenii v razlichnye vozrastnye periody zhizni [Features of somatic pathology in children with low, very low and extremely low birth weight at different ages of life (review of the world literature)]. Byulleten' sibirskoi meditsiny, 15(4), 140-149. https://doi.org/10.20538/1682-0363-2016-4-140-149 [in Russian].

[6] Martyniuk, V. Yu. (Ed.). (2016). Osnovy sotsialnoi pediatrii [Basis of social pediatrics] (Vol. 1). FOP Veres O. I. [in Ukrainian].

[7] Martyniuk, V. Yu. (Ed.). (2016). Osnovy sotsialnoi pediatrii [Basis of social pediatrics] (Vol. 2). FOP Veres O. I. [in Ukrainian].

[8] Pokhylko, V. I., Traverse, G. M., Tsvirenko, S. M., Zhuk, L. A., \& Oskomenko, M. M. (2016). Peredchasno narodzheni dity: suchasnyi pohliad na postnatalnu adaptatsiiu ta stan zdorov'ia u rannomu vitsi [Premature children: modern view on postnatal adaptation and health at an early age]. Visnyk problem biolohii i medytsyny, (1), 22-27. [in Ukrainian].

[9] Prusakov, V. F., Morozova, E. A, Marulina, V. I., Belousova, M. V., Utcusova, M. A., Gamirova, R. G., Knyazeva, O. V., Morozov, D. V. \& Zaikova, F. M. (2016). Rol' perinatal'nykh povrezhdenii nervnoi sistemy $v$ formirovanii nevrologicheskoi patologii detskogo vozrasta [The role of perinatal injuries of the nervous system in the formation of neurological disorders of childhood]. Vestnik sovremennoi klinicheskoi meditsiny, 9(2), 65-70. https://doi.org/10.20969/VSKM.2016.9(2).65-70 [in Russian].

[10] Rafikova, Y. S., Saprina, T. V., Loshkova, E. V., \& Mikhalev, E. V. (2015) Nedonoshennost' i ee otdalennye metabolicheskie posledstviya u detei i podrostkov [Prematurity and its long-term metabolic consequences in children and adolescents]. Pediatriya. Zhurnal im. G. N. Speranskogo, 94(5), 132-142. [in Russian].

[11] Remneva, O. V., Fadeeva, N. I., Korenovskii, Yu. V., \& Cherkasova, T. M. (2015). Prognozirovanie i rannyaya diagnostika tyazhelykh tserebral'nykh rasstroistv u nedonoshennykh novorozhdennykh [Prediction and early diagnosis of severe cerebral disorders in preterm infants]. Pediatriya. Zhurnal im. G. N. Speranskogo, 94(1), 13-18. [in Russian].

[12] Trishchynskaya, M. A, \& Svystilnyk, V. A. (2019). Rol klinichnoi diahnostyky nevrolohichnykh symptomiv pry henetychnykh khvorobakh [The neurological symptoms clinical diagnostics role in patients with genetic diseases]. Suchasni medychni tekhnolohii, (2), 69-73. https:// doi.org/10.34287/MMT.2(41).2019.44 [in Ukrainian].

[13] Joseph, R. M., O'Shea, T. M., Allred, E. N., Heeren, T., Hirtz, D., Paneth, N., Leviton, A., \& Kuban, K. C. K. (2017). Prevalence and associated features of autism spectrum disorder in extremely low gestational age newborns at age 10 years. Autism Research, 10(2), 224-232. https://doi.org/10.1002/aur.1644

[14] Ren, Y., Ao, Y., O'Shea, T. M., Burda, J. E., Bernstein, A. M. Brumm, A. J., Muthusamy, N., Ghashghaei, H. T., Carmichael, S. T., Cheng, L., \& Sofroniew, M. V. (2017). Ependymal cell contribution to scar formation after spinal cord injury is minimal, local and dependent on direct ependymal injury. Scientific Reports, 7, Article 41122. https:// doi.org/10.1038/srep41122

[15] Szpecht, D., Szymankiewicz, M., Nowak, I., \& Gadzinowski, J. (2016). Intraventricular hemorrhage in neonates born before 32 weeks of gestation - retrospective analysis of risk factors. Child's Nervous System, 32(8), 1399-1404. https://doi.org/10.1007/s00381-016-3127-x 